\title{
Screening Effects of Methanol Extracts of Diplotaxis tenuifolia and Reseda lutea on Enzymatic Antioxidant Defense Systems and Aldose Reductase Activity
}

\author{
Diplotaxis tenuifolia ve Reseda lutea Metanol Özütünün Antioksidan \\ Savunma Sistemi Enzimleri ve Aldoz Redüktaz Aktivitesi Üzerinde Olan \\ Etkisinin İncelenmesi
}

\author{
(D) Khalid Sharro ABDALRAHMAN', (D) Merve Gülşah GÜNEȘ', (D) Naznoosh SHOMALI*, (D) Belgin Sultan IŞGÖR², (D) Özlem YILDIRIM \\ 'Ankara University, Faculty of Science, Department of Biology, Ankara, Turkey \\ ${ }^{2}$ Atılım University, Faculty of Engineering, Department of Chemical Engineering and Applied Chemistry, Ankara, Turkey
}

\begin{abstract}
Objectives: The aim of the study was to investigate the effects of methanol extracts from the flowers and leaves of Diplotaxis tenuifolia and Reseda lutea on the activity of AR, CAT, GST, and GPx.

Materials and Methods: Total phenolic and flavonoid contents of the plant samples were evaluated using Folin-Ciocalteu reagent and aluminum chloride colorimetric methods. Also, the effects of extracts on CAT, GST, GPx, and AR enzyme activities were investigated using kinetic assays.

Results: The highest phenolic and flavonoid contents were detected in the methanol extract of $D$. tenuifolia leaves with $144.49 \pm 0.29$ mg gallic acid equivalent/L and $250.485 \pm 0.002$ quercetin equivalent/L, respectively. The best activity profile for GST and GPx were observed in the extract of leaves belonging to $D$. tenuifolia with $I C_{50}$ values of $121 \pm 0.05$ and $140 \pm 0.001 \mathrm{ng} / \mathrm{mL}$, respectively. According to the results, methanol extracts from leaves of $R$. lutea and $D$. tenuifolia showed no significant activity potential on AR. Moreover, none of the studied extracts demonstrated any reasonable CAT activation potential.
\end{abstract}

Conclusion: The results indicated that leaves of $D$. tenuifolia had good effect on the antioxidant enzymatic defense system, which it makes it a good constituent of the daily diet.

Key words: Diplotaxis tenuifolia, Reseda lutea, antioxidant enzymes, aldose reductase

öz

Amaç: Bu çalışmada Diplotaxis tenuifolia ve Reseda lutea'nın çiçek ve yapraklarından elde edilmiş olan metanol özütlerinin AR, CAT, GST ve GPx enzimlerinin aktiviteleri üzerinde olan etkilerinin araștırılması amaçlanmıştır.

Gereç ve Yöntemler: Bu çalışmada, bitki örneklerinin toplam fenolik ve flavonoid içeriği; Folin-Ciocalteu ve alüminyum klorür reaktiflerinin yardımıyla kolorimetrik yöntemlerle değerlendirilmiştir. Ayrıca özütlerin CAT, GST, GPx ve AR enzimlerinin aktiviteleri üzerindeki etkileri kinetik analizler ile araștırılmıştır.

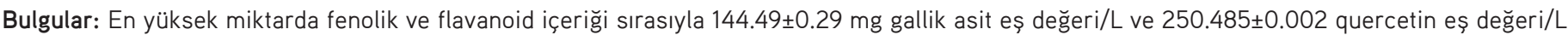
tespit edilmiştir. GST ve GPx için en iyi aktivite profilleri sırasıyla $121 \pm 0.05$ ve $140 \pm 0.001 \mathrm{ng} / \mathrm{mL} \mathrm{IC}$ (değerleri ile $D$. tenuifolia yaprak özütünde gözlemlenmiștir. Elde edilen sonuçlara göre, $R$. lutea ve $D$. tenuifolia'nın yapraklarından elde edilen metanol özütleri, AR enzimi üzerinde önemli ölçüde bir aktivite potansiyeli göstermemiştir. Bununla beraber, çalışılmış olan çiçek ve yaprak özütlerinin hiçbiri yeterli düzeyde CAT aktivasyonu gösterememiştir.

Sonuç: Çalıșma sonucunda, D. tenuifolia'nın yapraklarının antioksidan enzimatik savunma sistemi üzerinde iyi bir etkiye sahip olduğu gösterilmiştir. Bu sebeple günlük diyet için iyi bir besin kaynağı olarak kabul edilebilir.

Anahtar kelimeler: Diplotaxis tenuifolia, Reseda lutea, antioksidan enzimler, aldoz redüktaz

*Correspondence: E-mail: naznoosh_shomali@yahoo.com, Phone: +90 5542816336 ORCID-ID: orcid.org/0000-0002-7366-1569

Received: 18.01.2017, Accepted: 16.03.2017

Turk J Pharm Sci, Published by Galenos Publishing House. 


\section{INTRODUCTION}

Reactive oxygen species (ROS) is a term used to describe a number of reactive molecules and free radicals derived from molecular oxygen, which are generated by all aerobic species. These molecules are generated as by-products during the mitochondrial electron transport of aerobic respiration or by oxidoreductase enzymes and metal catalyzed oxidation. In normal physiologic conditions, a number of defense mechanisms have evolved to provide a balance between the production and removal of ROS, but alterations of the balance between ROS production and the capacity to detoxify reactive intermediates lead to oxidative stress. It has been caused to a wide variety of states, processess and metabolic diseases such as heart disease, severe neural disorders such as Alzheimer's and Parkinson's, and some cancers., ${ }^{1,2}$ Under oxidative stress, an organism has a variety of defense mechanisms to prevent or neutralize negative ROS effects. These are mainly based on enzymes such as catalase (CAT), superoxide dismutase (SOD), glutathione peroxidase (GPx), glutathione reductase (GR), and glutathione-S-transferase (GST) or non-enzymatic components such as vitamin $\mathrm{E}$, vitamin $\mathrm{C}$, glutathione, and flavonoids. ${ }^{3}$ GST is one of the phase II enzymes and plays a critical role in the detoxification and metabolism of many xenobiotic compounds. ${ }^{4}$ GPx has an important role as a catalyst in the reduction of hydro peroxides, including hydrogen peroxides $\left(\mathrm{H}_{2} \mathrm{O}_{2}\right)$, by using GSH. GPx also functions to protect the cell from oxidative damage. Several studies related dysfunctional GPx with cancer. ${ }^{5}$ CAT is a very important enzyme of living organisms, which catalyzes the decomposition of $\mathrm{H}_{2} \mathrm{O}_{2}$ to water and oxygen. Aldose reductase (AR) is a nicotinamide adenine dinucleotide phosphate (NADPH)-dependent enzyme and it has been implicated in the formation of cancer and diabetic complications such as retinopathy, neuropathy, nephropathy, and cardiovascular disorders. ${ }^{6}$

Plants synthesize a vast range of organic compounds that are traditionally classified as primary and secondary metabolites. Primary metabolites are compounds that have essential roles associated with photosynthesis, respiration, growth, and development. Other phytochemicals that accumulate in high concentrations in some species are known as secondary metabolites, which possess antioxidant activity. Antioxidant compounds found in different parts of plants involve phenolics, flavonoids, alkaloids, glycosides, tocopherols, carotenoids, and ascorbic acid. These are structurally diverse and many are distributed among a very limited number of species within the plant kingdom. ${ }^{7}$ Secondary metabolite compounds have played an important role in treating and preventing human diseases. They are important sources for new drugs and are also suitable lead compounds for further modification during drug development. ${ }^{4}$

Diplotaxis tenuifolia (L.) DC., commonly known as 'wild rocket', belongs to the Brassicaceae family. It was originally found as a crop in Mediterranean and Middle Eastern countries and became popular largely due its pungent aromas and tastes. ${ }^{8}$ In Turkish folk medicine, D. tenuifolia is known as "Yabani Roka" and wildly distributed in North and West parts of Turkey.
Phytochemical studies show that the aerial parts of $D$. tenuifolia contain significantly high concentration of flavonoids, tannins, glucosinolates, sterols, and vitamin C. ${ }^{9}$

The genus Reseda is one of the herbs in the Resedaceae family. In Turkey, this genus is represented by 15 species including Reseda lutea L. and Reseda luteola L. It is known as yellow mignonette or wild mignonette and has economic importance. It is widely used in the carpet and rug industry as a source of natural dye due to its high luteolin content. In addition to its staining properties, luteolin has attracted great scientific interest because of its pharmacologic activities. Luteolin displays numerous anti-inflammatory effects at micromolar concentrations, which cannot be completely explained by its antioxidant capacities. In addition, phytochemical analysis of aerial parts of $R$. lutea has shown the presence of flavonoid, anthocyanin, and glucosides. ${ }^{10}$

The aim of the present study was to evaluate the total amount of the phenolic and flavonoid contents of methanol extract obtained from the flowers and leaves of $D$. tenuifolia and $R$. lutea and to determine their effects on the activity of AR, CAT, GST, and GPx. These enzymes play critical roles in the antioxidant defense system.

\section{EXPERIMENTAL}

\section{Chemicals materials}

In this study, 4-aminoantipyrine, $\mathrm{H}_{2} \mathrm{O}_{2}$ and sodium azide $\left(\mathrm{NaN}_{3}\right)$ were provided by Acros, USA. Ethylenediaminetetraacetic acid (EDTA), Folin-Ciocalteu reagent, reduced glutathione (GSH), GR, horseradish peroxidase, CAT, gallic acid (GA), and quercetin hydrate were supplied by Sigma Aldrich, Germany. Lithium sulphate $\left(\mathrm{Li}_{2} \mathrm{SO}_{4}\right)$ and NADPH were purchased from Gerbu, Germany. All other chemicals used were analytical grade and provided by Sigma Aldrich, Germany.

\section{Plant materials}

Plant samples of $D$. tenuifolia and $R$. lutea were harvested in July 2010 from Ankara, Turkey, and were authenticated by Prof. Dr. Fatmagül Geven, in the Department of Biology, Ankara University. The plant specimens with their localities and the necessary field records were recorded and numerated as voucher specimen numbers. The voucher numbers of D. tenuifolia and R. lutea were FG-2010-10 and FG-2010-13, respectively. They were deposited in the herbarium department at Ankara University.

\section{Extraction of plant}

Different parts of fresh plant samples (flowers and leaves) were washed with tap water and dried at room temperature before analysis. For methanol extraction, $2 \mathrm{~g}$ of dried samples were weighed and ground into a fine powder with liquid nitrogen, then mixed with $20 \mathrm{~mL}$ methyl alcohol at room temperature in $160 \mathrm{rpm}$ for $24 \mathrm{~h}$. The obtained extract was filtered over Whatman No. 1 paper and the filtrate was collected. Methanol was then removed using a rotary evaporator at $40^{\circ} \mathrm{C}$ to obtain a dry extract. The obtained product was dissolved in DMSO and kept in the dark $\left(4^{\circ} \mathrm{C}\right)$ to be prevent oxidative damage until analysis." 


\section{Total phenolics determination}

The total phenolic content of the plant extracts was determined using the method of Slinkard and Singleton. ${ }^{12}$ Each plant extract solution $(0.1 \mathrm{~mL})$ was mixed with $2 \mathrm{~mL}$ of a $2 \%(\mathrm{w} / \mathrm{v})$ sodium carbonate solution and vortexed strongly. After $5 \mathrm{~min}, 0.1 \mathrm{~mL}$ of $50 \%$ Folin-Ciocalteu's reagent (w/v) was added and vortexed, then incubated for $1 \mathrm{hr}$ at room temperature. Afterwards, the absorbance of each mixture was measured at $750 \mathrm{~nm}$ using an ultraviolet (UV) spectrophotometer (HP 8453 A, USA). Results were evaluated using 50, 100, 200 and $400 \mathrm{mg} / \mathrm{L}$ of GA as a standard curve and recorded as milligrams (mg) GA equivalent/L of extract.

\section{Total flavonoid determination}

The total concentration of flavonoids in the extracts was determined using aluminum chloride colorimetry, which was previously described ${ }^{13} ; 0.1 \mathrm{~mL}$ of each plant extract was separately mixed with $0.15 \mathrm{~mL}$ of $95 \%$ ethanol, $0.01 \mathrm{~mL}$ of $10 \%$ aluminum chloride, $0.01 \mathrm{~mL}$ of $1 \mathrm{M}$ sodium acetate, and 0.25 $\mathrm{mL}$ of DMSO. The mixture was incubated at room temperature for $30 \mathrm{~min}$ and the absorbance of the reaction was measured at $415 \mathrm{~nm}$ with the UV spectrophotometer (HP 8453 A, USA). A standard curve was calculated by preparing quercetin solutions at different concentrations for 25, 50, 100, 150, and $200 \mathrm{mg} / \mathrm{L}$. The total flavonoid content of the extract was expressed as milligrams (mg) quercetin equivalent/L of extract.

\section{Isolation of cytosol from bovine liver}

Bovine liver was obtained from a slaughterhouse in Kazan, Ankara, Turkey. The liver samples were homogenized in 10 $\mathrm{mM}$ potassium phosphate buffer $(\mathrm{pH} 7.0)$, containing $0.15 \mathrm{M}$ $\mathrm{KCl}, 1.0 \mathrm{mM}$ EDTA, and $1.0 \mathrm{mM}$ of DTT, using a glass Teflon homogenizer and then centrifuged at $10.000 \mathrm{~g}$ for $20 \mathrm{~min}$. The supernatant was filtered through cheesecloth and the filtrate was centrifuged at $30.000 \mathrm{~g}$ for $60 \mathrm{~min}$. The collected supernatants were filtered again and the resultant filtrate was considered as cytosol. ${ }^{14}$ The prepared homogenates, containing $46.41 \mathrm{mg}$ protein $/ \mathrm{mL}$, were kept in ultra-low freezer $\left(-80^{\circ} \mathrm{C}\right)$ for future use. The total protein content was determined using the Lowry method. ${ }^{15}$

\section{Isolation of aldose reductase from bovine liver}

Bovine liver was obtained from a slaughterhouse in Kazan, Ankara, Turkey. The liver samples were cut into small pieces and washed with $1.0 \mathrm{mM}$ EDTA. It was then weighed and homogenized with threefold $1.0 \mathrm{mM}$ EDTA $50 \mu \mathrm{M}$ PMSF and centrifuged at $+4^{\circ} \mathrm{C}, 10.000 \mathrm{rpm}$ for $30 \mathrm{~min}$. To obtain a $40 \%$ saturation, $22.6 \mathrm{~g}$ ammonium sulfate was added to every 100 $\mathrm{mL}$ supernatant solution and mixed for $5 \mathrm{~min}$ on a magnetic stirrer and then centrifuged at $+4^{\circ} \mathrm{C}, 10.000 \mathrm{rpm}$ for $25 \mathrm{~min}$. To obtain $50 \%$ and $75 \%$ saturations, the previous method was repeated adding $5.8 \mathrm{~g}$ and $15.9 \mathrm{~g}$ of ammonium sulfate to the $100 \mathrm{~mL}$ supernatant solution, respectively. The obtained pellets were dissolved with $50 \mathrm{mM}$ sodium chloride and kept in a deepfreeze at $-80^{\circ} \mathrm{C} .^{16}$

\section{Assay of glutathione-S-transferase}

GSTs activity was determined against the substrate 1-chloro-2, 4-dinitrobenzene (CDNB), by monitoring thioether formation at $340 \mathrm{~nm} .^{17}$ Briefly described, the assay mixture containing plant extracts solution (final concentration in the range of 7-476 ng/mL), $200 \mathrm{mM}$ potassium phosphate buffer $(\mathrm{pH} 6.5)$ with $50 \mathrm{mM} \mathrm{CDNB}$ and $3.2 \mathrm{mM} \mathrm{GSH}$, and bovine liver cytosolic fractions ( $0.782 \mathrm{mg}$ protein $/ \mathrm{mL}$ ) was prepared and used as the enzyme source to measure GST activity. GSH-CDNB conjugate formation was followed in a $250-\mu \mathrm{L}$ total volume assay using a multimode microplate reader (Specra Max M2e, USA) at 340 $\mathrm{nm}$ for 240 seconds. The initial rates of enzymatic reactions were determined as nanomoles of the conjugation product of GSH and reported as $\mathrm{nmol} / \mathrm{min} / \mathrm{mg}$ protein.

\section{Assay of aldose reductase}

AR activity was determined against the substrate, DLGlyceraldehyde, by monitoring the oxidation of NADPH to $\mathrm{NADP}^{+}$at $340 \mathrm{~nm} .^{18}$ In brief, the assay mixture consisting of plant extract $(5 \mu \mathrm{L}$ ) solution (final concentration in the range of $7-476 \mathrm{ng} / \mathrm{mL}), A R(4.54 \mathrm{mg} / \mathrm{mL}) \mathrm{Li}_{2} \mathrm{SO}_{4}(320 \mathrm{mM}-400 \mathrm{mM})$, NADPH $\left(9 \times 10^{-5} \mathrm{M}\right) \mathrm{KP}$ buffer $(50 \mathrm{mM}, \mathrm{pH} 6.2)$, DL-GA $\left(6 \times 10^{-4} \mathrm{M}\right)$ was prepared and used as the enzyme source to measure $A R$ activity. $\mathrm{NADP}^{+}$oxidation was followed in $0.25 \mathrm{~mL}$ total volume assay using a multimode microplate reader at $340 \mathrm{~nm}$ for $4 \mathrm{~min}$. The initial rates of enzymatic reactions were determined and reported as $\mathrm{nmol} / \mathrm{min} / \mathrm{mg}$ protein.

\section{Assay of glutathione peroxidase}

GPx activity was measured using a previously reported method. 19,20 Also, GPx activity was measured against the substrate, tertiary butyl hydro-peroxide (t-BuOOH), and the decrease in NADPH was monitored at $340 \mathrm{~nm}$. GPx activity changes were measured using purified GPx $\left(37.5 \times 10^{-3} \mathrm{U} / \mathrm{mL}\right)$ and plant extracts (7-476 ng/mL) or control (DMSO alone), with 2.0 $\mathrm{mM}$ GSH, $0.25 \mathrm{mM}$ NADPH, GSH-reductase (GR, 0.5 unit $/ \mathrm{mL}$ ) and $0.3 \mathrm{mM}$ t-BuOOH , in $50 \mathrm{mM}$ Tris- $\mathrm{HCl}(\mathrm{pH}=8.0)$. The reaction was initiated by adding GPx and the change in absorbance was recorded at $340 \mathrm{~nm}$ for 5 min using a multimode microplate reader.

\section{Assay of catalase}

CAT inhibition was determined by monitoring a red quinoneimine dye remaining $\mathrm{H}_{2} \mathrm{O}_{2} \cdot{ }^{21,22}$ The assay was miniaturized for microplate application and contained plant extraction solutions with a final concentration in the range of $7-476 \mathrm{ng} / \mathrm{mL}, 50 \mathrm{mM}$ phosphate buffer ( $\mathrm{pH} 7.0$ ), $20 \mathrm{U} / \mathrm{mL}$ purified bovine liver CAT, and $0.0961 \mathrm{mM} \mathrm{H}_{2} \mathrm{O}_{2}$. The reaction was stopped using $\mathrm{NaN}_{3}$ and incubated at room temperature for $5 \mathrm{~min}$, followed by incubation with chromogen at room temperature for $40 \mathrm{~min}$ and then the absorbance was read at $520 \mathrm{~nm}$. The enzyme activity was calculated with respect to the $\mathrm{H}_{2} \mathrm{O}_{2}$ remnant, which was determined using a calibration curve constructed in the range of 9.61-307.6 $\mu \mathrm{M} \mathrm{H}_{2} \mathrm{O}_{2}$.

\section{Data analysis}

The data analysis was performed using the Graphpad Prism 6.0 software. The activity of extracts against enzyme targets was calculated as $50 \%$ inhibitory concentration $\left(\mathrm{IC}_{50}\right)$ values obtained from dose-response curves. The enzyme calibration 
and the dose-response curve construction were accomplished using 2-3 independent experiments, each in duplicate or triplicate using a multimode microplate reader, in 96-well microplates.

\section{RESULTS}

Each extract was prepared by dissolving $2 \mathrm{~g}$ of dry samples in $20 \mathrm{~mL}$ of methanol. The extraction yields for $D$. tenuifolia leaf samples was $13.02 \%$, and $10.15 \%$ and $6.02 \%$ for R. lutea flower and leaf samples, respectively (Table 1).

The total phenolic contents of extracts were determined by using Folin-Ciocalteu's method. Additionally, the total amount of flavonoids in extracts were determined using aluminum chloride colorimetry. According to the results, the methanol extract of $D$. tenuifolia leaves has a high amount of total phenolic and flavonoid contents. The results of total phenolic and flavonoid contents of the methanol extracts of the plant samples are listed in Table 1.

The activation percent profile of GST, GPx, CAT, and AR enzymes and $I_{50}$ values of the methanol extracts of plant samples are presented in Table 2. GST activity was determined against the substrate, CDNB, by monitoring the thioether formation at 340 $\mathrm{nm}$. In order to calculate the percentage of GST activity and $I_{50}$ values, the utilized final concentration of plant extracts in the assay was taken between $7-476 \mathrm{ng} / \mathrm{mL}$. According to the results, which are presented in Table 2 , the best activity effect was exhibited in the crude methanol extract of $D$. tenuifolia leaves with $\mathrm{IC}_{50}$ value of $121 \pm 0.05 \mathrm{ng} / \mathrm{mL}$.

The activity of GPx was determined as the amount of enzyme that converted $1 \mu \mathrm{M}$ of NADPH per min in $1 \mathrm{~mL}$ which is expressed as $\mathrm{U} / \mathrm{mg}$ of total protein. The final concentration of plant extracts within concentration range of $7-476 \mathrm{ng} / \mathrm{mL}$ were used in the assay to calculate the percentage of GPx activity and $\mathrm{IC}_{50}$ values. The best activity profile for GPx was observed in the extract of leaves belonging to $D$. tenuifolia with an $I C_{50}$ value of $140 \pm 0.001 \mathrm{ng} / \mathrm{mL}$.
AR activity was determined using the substrate DLGlyceraldehyde, by monitoring the oxidation of NADPH to $\mathrm{NADP}^{+}$at $340 \mathrm{~nm}$. The methanol extracts from leaves of $R$. lutea and $D$. tenuifolia showed no significant activity with AR (Table 2). In addition, none of the studied extracts showed reasonable CAT activity potential.

\section{DISCUSSION}

The aim of the present study was to evaluate the total amount of the phenolic and flavonoid contents of methanol extract obtained from the flowers and leaves of $D$. tenuifolia and $R$. lutea. Furthermore, it was aimed to determine the effects of the extract on the activity of AR, CAT, GST and GPx. Phenolic compounds have at least one or more aromatic rings with one or more hydroxyl groups attached. ${ }^{23}$ Many phenolic compounds and flavonoids have been reported to have potential for antioxidant, anticancer, anti-atherosclerotic, antibacterial, antiviral, and antiinflammatory activities. ${ }^{24}$ Flavonoids are phenolic compounds found throughout the plant kingdom. They have been shown to possess a variety of biologic activities in organisms. Many flavonoids possess antitumor, anti-proliferation, cell cycle arrest, induction of apoptosis and differentiation, inhibition of angiogenesis, antioxidant and reversal of multidrug resistance activities. ${ }^{25-27}$ Different studies have shown that plant extracts with high polyphenol contents are known as a good source of antioxidant activity. ${ }^{28-30}$

In this study, for the first time, it was shown that the methanol extract from leaves of $D$. tenuifolia contains a high amount of total phenolic and flavonoid compounds. The results indicated that the methanol extract from the leaves of $D$. tenuifolia had a significant effect on GST and GPx activities. Therefore, it can be said that the leaves of $D$. tenuifolia have a good effect on the antioxidant enzymatic defense system. However, it is found that the leaf extracts of $D$. tenuifolia had no effect on AR and CAT activities. It was also demonstrated that the methanol extract from leaves of $R$. lutea contained more phenolic and flavonoid

Table 1. The percentage yield of dry products obtained from methanol extraction procedure with total polyphenol and flavonoid contents of each plant sample

\begin{tabular}{llllll} 
Family & Species & Parts of plants & $\%$ yield & TPC mg GAE/L & Flavonoid mgQE/L \\
\hline Brassicaceae & Diplotoxis tenuifolia & Leaves & 13.02 & $144.49 \pm 0.29$ & $250.485 \pm 0.002$ \\
\hline Resedaceae & Reseda lutea & Flowers & 10.15 & $109.01 \pm 0.03$ & $78.72 \pm 0.03$ \\
\cline { 2 - 6 } & & Leaves & 6.02 & $133.52 \pm 0.02$ & $196.80 \pm 0.01$ \\
\hline
\end{tabular}

Table 2. Glutathione-S-transferase, glutathione peroxidase, catalase, and aldose reductase percentage activities

\begin{tabular}{|c|c|c|c|c|c|c|c|c|c|c|}
\hline \multirow[t]{2}{*}{ Family } & \multirow[t]{2}{*}{ Species } & \multirow{2}{*}{$\begin{array}{l}\text { Parts of } \\
\text { plants }\end{array}$} & \multicolumn{2}{|c|}{ GST } & \multicolumn{2}{|l|}{ GPx } & \multicolumn{2}{|c|}{ CAT } & \multicolumn{2}{|l|}{ AR } \\
\hline & & & $\%$ & $\mathrm{IC}_{50} \mathrm{ng} / \mathrm{mL}$ & $\%$ & $\mathrm{IC}_{50} \mathrm{ng} / \mathrm{mL}$ & $\%$ & $\mathrm{IC}_{50} \mathrm{ng} / \mathrm{mL}$ & $\%$ & $\mathrm{IC}_{50} \mathrm{ng} / \mathrm{mL}$ \\
\hline Brassicaceae & $\begin{array}{l}\text { Diplotoxis } \\
\text { tenuifolia }\end{array}$ & Leaves & 72 & $121 \pm 0.05$ & 84 & $140 \pm 0.001$ & ND & ND & 5 & $231 \pm 0.0$ \\
\hline \multirow[t]{2}{*}{ Resedaceae } & Reseda lutea & Flowers & 36 & $149 \pm 0.004$ & 84 & $490 \pm 0.05$ & ND & ND & ND & ND \\
\hline & & Leaves & 70 & $403 \pm 0.015$ & $N D^{*}$ & ND & ND & ND & 20 & $601 \pm 0.002$ \\
\hline
\end{tabular}

ND: Not determined, GST: Glutathione-S-transferase, GPx: Glutathione peroxidase, CAT: Catalase, AR: Aldose reductase 
contents than its flower samples. However, the flower extract of $R$. lutea showed good effects on GPx activity than the leaf extract and the opposite of this situation was seen in the GST results.

In a previous study, D. tenuifolia was analyzed for active compounds and antitumor actions on colorectal cancer cells. The results showed that $D$. tenuifolia was a good source of carotenoids, phenolics, and glucosinolate compounds. It also has antitumor activities on colorectal cancer. ${ }^{31}$ Marrelli et al. ${ }^{32}$ evaluated thirteen hydro alcoholic extracts of edible plants from Southern Italy for their in vitro antioxidant and antiproliferative activity on breast cancer MCF-7, hepatic cancer HepG2, and colorectal cancer LoVo. They showed that the lowest antioxidant activity was exhibited by $D$. tenuifolia (DT) extract. In addition, the authors reported that $D$. tenuifolia extract was able to induce an inhibitory activity of cell proliferation of more than $40 \%$.

In another study, the polyphenol content and biologic activities of the main component of $D$. simplex extract was investigated. The analyzed extracts showed that flower extracts exhibited a potent in vitro antioxidant capacity using oxygen radical absorbance capacity and displayed a strong anti-inflammatory activity and inhibited nitric oxide release. The findings suggested that the Diplotaxis flower was a valuable source of antioxidants and anti-inflammatory agents. ${ }^{33}$ Durazzo et al. ${ }^{34}$ studied the nutritional and antioxidant properties of wild rocket [D. tenuifolia (L.) DC.]. The authors determined the bioactive molecular content (vitamin C, quercetin, lutein) and showed bioactivity of polyphenolic extracts from the edible part of rocket in Caco-2 cells. Atta et al. ${ }^{35}$ isolated five main flavonoid glycosides from the ethanol extract of $D$. harra and identified them as quercetin, isorhamnetin 3-rhamnoside, isorhamnetin 3-o-rutinoside, isorhamnetin 3-glucosyl-4rhamnoside and isorhamnetin 3-o- $\beta$-glucoside. They also evaluated the alcoholic extract of plants against some bacterial strains that showed moderate antibacterial activity. MartínezSánchez et al. ${ }^{9}$ studied antioxidant compounds, flavonoids, and vitamin $\mathrm{C}$, and also the antioxidant activity of four species from Brassicaceae vegetables used for salads such as watercress (Nasturtium oficinale), mizuna (Brassica rapa), wild rocket ( $D$. tenuifolia), and salad rocket (Eruca sativa). They analyzed the characterization of phenolic compounds and they showed that the leaves of watercress, mizuna, wild rocket, and salad rocket, presented high contents of antioxidant compounds such as flavonoids and vitamin C. Therefore, they are good dietary sources of antioxidants with an important variability of bioactive compounds.

However, no pharmacologic studies have been performed with $R$. lutea extracts to date, but Reseda species have been reported to possess various pharmacologic properties such as anti-inflammatory, antioxidant, antibacterial, and antimicrobial effects. For the first time, Benmerache et al. ${ }^{36}$ isolated six flavonoids from the aerial parts of $R$. phyteuma. They also found that the butanolic extract exhibited good antioxidant and antimicrobial activities. $R$. luteola $L$. has been used as a dye due to its high luteolin content since ancient times. Woelfl et al. ${ }^{37}$ determined anti-proliferative and apoptosis-inducing effects of the $R$. luteola extract RF-40. They found that it contained $40 \%$ flavonoids, primarily luteolin, luteolin-7-0-glucoside, and apigenin. Further, it was observed that the isolated flavonoids dose-dependently inhibited cell proliferation and induced apoptotic oligonucleosomes in PHA-stimulated peripheral blood mononuclear cells. Moreover, they showed that Reseda extract was an interesting raw material dyeing purposes and for further pharmacologic investigation. In another study, Berrehal et al. ${ }^{38}$ investigated the methanolic and $n$-butanolic extracts of $R$. duriaeana and $R$. villosa for their antioxidant activity. The authors indicated that the methanolic and n-butanolic extracts of $R$. duriaeana exhibited better antioxidant activity than the respective extracts of $R$. villosa. This may be explained by the presence of more quercetin derivatives in $R$. duriaeana.

From a consideration of ethnobotanical information, seeds of 45 Scottish plant species were obtained from authentic seed suppliers. The n-hexane, dichloromethane (DCM), and methanol $(\mathrm{MeOH})$ extracts were assessed for free radical scavenging activity in a DPPH assay. The results showed that the methanol extract of $R$. lutea seeds exhibited moderate levels of free radical scavenging activity. Also, the n-hexane extract was much less active than the $\mathrm{MeOH}$ and DCM extracts. ${ }^{39}$ Tawaha et al. ${ }^{40}$ determined the relative levels of antioxidant activity and the total phenolic content of aqueous and methanolic extracts of a total of 51 Jordanian plant species. They indicated that the aqueous and methanolic extracts of $R$. lutea had remarkably high total phenolic contents and showed good levels of antioxidant activity.

\section{CONCLUSION}

In conclusion, the biologic potential of $D$. tenuifolia and $R$. lutea on the antioxidant defense system such as GST, GPx, CAT, and $A R$ were considered in this research. It was shown that the methanol extract of $D$. tenuifolia leaves had a high amount of phenolic and flavonoid compounds. Also, it is indicated that it has good activity potential on GPx and GST. These results might be related to the high content of phenolics and flavonoids found in the species. This work highlights the importance of $D$. tenuifolia as a part of the daily diet.

\section{ACKNOWLEDGEMENTS}

This study was supported by the grant from The Coordination of Scientific Research Projects of Ankara University awarded to Prof. Dr. Özlem Yıldırım (Grant No:13L4240008).

Conflict of Interest: No conflict of interest was declared by the authors.

\section{REFERENCES}

1. Hancock JT, Desikan R, Neill SJ. Role of Reactive Oxygen Species in Cell Signaling Pathways. Biochem Soc Trans. 2001;29:345-350.

2. Ye ZW, Zhang J, Townsend DM, Tew KD. Oxidative stress, redox regulation and diseases of cellular differentiation. BiochiM Biophys Acta. 2015;1850:1607-1621. 
3. Lushchak VI. Free radicals, reactive oxygen species, oxidative stress and its classification. Chem Biol Interact. 2014;224:164-175.

4. Ata A, Van den Bosch SA, Harwanik DJ, Pidwinski GE. Glutathione S-transferase- and acetylcholinesterase-inhibiting natural products from medicinally important plants. Pure and Appl Chem. 2007;79:22692276.

5. Hu YJ, Diamond AM. Role of glutathione peroxidase 1 in breast cancer: loss of heterozygosity and allelic differences in the response to selenium. Cancer Res. 2003;63:3347-3351.

6. Lee EH, Song DG, Lee JY, Pan CH, Um BH, Jung SH. Inhibitory Effect of the Compounds Isolated from Rhus verniciflua on Aldose Reductase and Advanced Glycation Endproducts. Biol Pharm Bull. 2008;31:1626-1630.

7. Croteau R, Kutchan TM, Lewis NG. Natural products (secondary metabolites. Biochemistry and Molecular Biology of Plant. 2000;24:12501318.

8. Bell L, Wagstaff C. Glucosinolates, Myrosinase Hydrolysis Products, and Flavonols Found in Rocket (Eruca sativa and Diplotaxis tenuifolia). J Agric Food Chem. 2014;62:4481-4492.

9. Martínez-Sánchez A, Gil-Izquierdo A, Gil MI, Ferreres F. A Comparative Study of Flavonoid Compounds, Vitamin C, and Antioxidant Properties of Baby Leaf Brassicaceae Species. J Agric Food Chem. 2008;56:23302340.

10. Radulovic NS, Zlatkovic DB, llic-Tomic T, Senerovic L, Nikodinovic-Runic J. Cytotoxic effect of Reseda lutea L.: A case of forgotten remedy. J Ethnopharmacol. 2014;153:125-132.

11. Moghaddam NS, Isgor BS, Isgor YG, Geven F, Yildirim O. The Evaluation of Inhibitory Effects of Selected Plant Extracts on Antioxidant Enzymes. Fresenius Environmental Bulletin. 2015;24:63-70.

12. Slinkard K, Singleton VL. Total phenol analyses: Automation and comparison with manual methods. Am J Enol Vitic. 1977;28:49-55.

13. Chang CC, Yang MH, Wen HM, Chern JC. Estimation of total flavonoid content in propolis by two complementary colorimetric methods. J Food Drug Anal. 2002;10:178-182.

14. Çoruh N, Sagdicoglu Celep AG, Ozgokce F, Iscan M. Antioxidant capacities of Gundelia tourneforii L. extracts and inhibition on glutathioneS-transferase activity. J Food Chem. 2007;100:1249-1253.

15. Lowry OH, Rosebrough NJ, Farr AL, Randall RJ. Protein measurement with the Folin phenol reagent. J Biol Chem. 1951;193:265-275.

16. Onay M. Investigation for Natural Extract Inhibitors of Bovine Lens Aldose Reductase Responsible for the Formation of Diabetis Dependent Cataract. Middle East Technical University; Ankara, Turkey; 2008.

17. Habig WH, Pabst MJ, Jakoby WB. Glutathione-S-transferases the first enzymatic step in mercapturic acid formation. J Biol Chem. 1974;249:7130-7139.

18. Hayman S, Kinoshita JH. Isolation and Properties of Lens Aldose Reductase. J Biol Chem. 1965;240:877-882.

19. Geller BL, Winge DR. Subcellular distribution of superoxide dismutases in rat liver. Methods Enzymol. 1984;105:105-114.

20. Weydert CJ, Cullen JJ. Measurement of superoxide dismutase, catalase and glutathione peroxidase in cultured cells and tissue. Nat Protoc. 2009;5:51-66.

21. Bai JZ, Saafi EL, Zhang S, Cooper GJ. Role of Ca2+ in apoptosis evoked by human amylin in pancreatic islet beta-cells. Biochem J. 1999;343:53-61.
22. Yıldırım Ö, Aras S, Ergül A. Response of antioxidant systems to shortterm $\mathrm{NaCl}$ stress in grapevine rootstock-1616c and Vitis vinifera L. cv. Razaki. Acta Biol Cracoviensia Series Bot. 2004:46:151-158.

23. Fresco P, Borges F, Diniz C, Marques MP. New insights on the anticancer properties of dietary polyphenols. Med Res Rev. 2006;26:747-766.

24. Udenigwe CC, Ata A, Samarasekera R. Glutathione-S-transferase inhibiting chemical constituents of Caesalpinia bonduc. Chem Pharm Bull (Tokyo). 2007:55:442-445.

25. Ren W, Qia Z, Wang H, Zhu L, Zhang L. Flavonoids: promising anticancer agents. Med Res Rev. 2003;23:519-534.

26. Valko M, Leibfritz D, Moncol J, Cronin MT, Mazur M, Telse J. Free radicals and antioxidants in normal physiological functions and human disease. Int J Biochem Cell Biol. 2007;39:44-84.

27. Zeng S, Liu W, Nie FF, Zhao Q, Rong JJ, Wang J, Tao L, Qi Q, Lu N, Li ZY, Guo QL. LYG-202, a new flavonoid with a piperazine substitution, shows antitumor effects in vivo and in vitro. Biochem Biophys Res Commun. 2009;385:551-556.

28. Aruoma OI, Bahorun T, Jen LS. Neuroprotection by bioactive components in medicinal and food plant extracts. Mutat Res. 2003;544:203-215.

29. Cai YZ, Luo Q, Sun M, Corke H. Antioxidant activity and phenolic compounds of 112 traditional Chinese medicinal plants associated with anticancer. Life Sci. 2004;74:2157-2184.

30. Cai YZ, Mei Sun, Jie Xing, Luo Q, Corke H. Structure-radical scavenging activity relationships of phenolic compounds from traditional Chinese medicinal plants. Life Sci. 2006;78:2872-2888.

31. Ramos-Bueno RP, Rincón-Cervera MA, González-Fernández MJ, GuilGuerrero JL. Phytochemical Composition and Antitumor Activities of New Salad Greens: Rucola (Diplotaxis tenuifolia) and Corn Salad (Valerianella locusta). Plant Foods Hum Nutr. 2016;27:197-203.

32. Marrelli M, Cristaldi B, Menichini F, Conforti F. Inhibitory effects of wild dietary plants on lipid peroxidation and on the proliferation of human cancer cells. Food Chem Toxicol. 2015;86:16-24.

33. Oueslatiab S, Ellilic A, Legaultb J, Pichetteb A, Ksouria R, Lachaalc M, Karray-Bouraoui N. Phenolic content, antioxidant and anti-inflammatory activities of Tunisian Diplotaxis simplex (Brassicaceae). Nat Prod Res. 2015;29:1189-1191.

34. Durazzo A, Azzini E, Lazzè MC, Raguzzini A, Pizzala E, Maiani M. Italian Wild Rocket [Diplotaxis tenuifolia (L.) DC.]: Influence of Agricultural Practices on Antioxidant Molecules and on Cytotoxicity and Antiproliferative Effects. Agriculture. 2013;3:285-298.

35. Atta EM, Hashem Al, Ahmed AM, Elqosyd MS, Jasparse M, El-Sharkaw ER. Phytochemical studies on Diplotax isharra growing in Sinai. Euro J of Chem. 2011;2:535-538.

36. Benmerache A, Berrehal D, Khalfallah A, Kabouche A, Semra Z, Kabouche Z. Antioxidant, antibacterial activities and flavonoids of Reseda phyteuma L. Der Pharma Lettre. 2012;4:1863-1867.

37. Woelfl U, Simon-Haarhaus B, Merfort I, Schempp CM. Reseda luteola L. Extract Displays Antiproliferative and Pro-Apoptotic Activities that are Related to its Major Flavonoids. Phytother Res. 2010;24:1033-1036.

38. Berrehal D, Khalfallah A, Betina SB, Kabouche Z, Kacem N, Kabouche A, Calliste CA, Duroux JL. Comparative antioxidant activity of two Algerian Reseda species. Chem Nat Compds. 2010;4:456-458.

39. Kumarasamy Y, Cox PJ, Jaspars M, Nahar L, Sarker SD. Screening seeds of Scottish plants for antibacterial activity. J Ethnophar. 2002;83:73-77.

40. Tawaha K, Alali FQ, Gharaibeh M, Mohammad M, El-Elimat T. Antioxidant activity and total phenolic content of selected Jordanian plant species. Food Chem. 2007;104:1372-1378. 